\title{
BMJ Global Health Harnessing the peace dividends of health
}

To cite: Al Mandhari A, Ghaffar A, Etienne CF. Harnessing the peace dividends of health. BMJ Global Health 2021;6:e006287. doi:10.1136/ bmjgh-2021-006287

Received 12 May 2021 Accepted 15 May 2021

Check for updates

(c) Author(s) (or their employer(s)) 2021. Re-use permitted under CC BY-NC. No commercial re-use. See rights and permissions. Published by BMJ.

${ }^{1}$ World Health Organization Regional Office for the Eastern Mediterranean, Cairo, Egypt ${ }^{2}$ Alliance for Health Policy and Systems Research, World Health Organization, Geneva, Switzerland

${ }^{3}$ Pan American Health Organization, Washington, DC, USA

Correspondence to

Dr Abdul Ghaffar;

ghaffara@who.int
Building peace is usually considered the job and domain of diplomats. Health, however, is also a bridge to peace, and policymakers have identified the multifaceted linkages between health and peace. ${ }^{1}$ While conflict and violence affect physical and mental health, damaging health systems and other determinants of health, peace is also a critical prerequisite for health and well-being. ${ }^{2}$ The drivers of conflicts are often health related, and health can be a goal to help competing groups to unite for peace. ${ }^{3}$ The ongoing COVID-19 pandemic while straining already fragmented health systems and societies offers new opportunities to build, promote and sustain peace in conflict-affected countries. ${ }^{4}$

The concept of Health for Peace has a long history, with a 'Peace through Health' framework developed in the 1990s. ${ }^{5}$ This framework conceptualises war as a disease, with interventions targeting preconflict, ongoing conflict and postconflict settings. Building on the work of the Pan American Health Organization (PAHO), the WHO formally launched its Health as a Bridge for Peace framework in $1997 .{ }^{6}$ In 2019, the WHO Eastern Mediterranean Regional Office (EMRO) together with the Government of Oman launched the Health for Peace (HoPE) initiative. This new initiative aims to raise awareness and promote peace through diplomacy, programming efforts and building capacity. The initiative is aligned with the 2016 United Nations (UN) 'sustaining peace' resolutions, which called on all UN agencies to consider their contributions to peace building, ${ }^{7}$ and with WHO's Thirteenth General Programme of Work which aims to 'identify, harmonise and systematise its contributions to sustaining peace in fragile-, conflict- and violenceaffected settings'.

Since the launch of this initiative, the WHO Director-General has called for using health as a bridge for peace. ${ }^{9}$ Health workers are being equipped with peace building skills, and the recent Commission on the Social
Determinants of Health in the Eastern Mediterranean region documented conflict as a macrodeterminant of health. ${ }^{10}$ WHO has also released a white paper outlining WHO's contribution to the 'sustaining peace' agenda. ${ }^{11}$ Despite recent momentum, the evidence base to support, implement and evaluate 'Health for Peace' programmes remains limited. Many public health professionals, policymakers and researchers do not fully recognise or appreciate the linkages between health and peace. As a result, policymakers in fragile, conflict and violenceaffected settings do not consider peace when developing and implementing interventions and health policies. ${ }^{12}$

Yet there is a growing opportunity to harness the potential of health to promote, build and sustain peace. According to the World Bank, violent conflict has spiked and increased in complexity since $2010 .{ }^{13}$ Multiple global trends may exacerbate fragility, including climate change, huge increases in noncommunicable diseases, rising inequality, new technologies and the impact of COVID-19. By the end of 2019, a total of 79.5 million people had been forcibly displaced globally, $85 \%$ of whom were hosted in low and middle-income countries. Peace is central to achieving the well-being and ambitions of development and humanitarian community and health can be a bridge for peace. Given the global status of conflict and that most of the world's extreme poor could live in fragile, conflict and violence-affected settings by 2030 , investment in research and understanding to advance Health for Peace has never been more critical and necessary.

\section{A CALL FOR PAPERS}

Building on previous efforts and calls, ${ }^{14}$ the leadership of WHO EMRO, PAHO and the Alliance for Health Policy and Systems Research are together issuing a call for papers for a special issue of BMJ Global Health on Peace for Health. This special issue will focus 
broadly on themes and questions, like how can health, directly and indirectly, promote peace as well as mitigate and prevent conflict? Are there specific examples or case studies of where or when this has occurred? Have they been documented? Can they be replicated? What lessons do they offer? What are the fundamental principles of 'health for peace'? How should it be conceptualised and assessed? What frameworks or methodologies should be applied and used? How might such considerations affect health policy and practice?

This special issue will strengthen the evidence base for effective interventions. It will also highlight best practices and promote learning and research. By raising the profile and deepening attention to Health for Peace, it is hoped that more opportunities will be created for constructive dialogue to advance this important agenda. We call for submissions across article types, including original research, analysis and practice articles, to consider these questions and themes by 15 October 2021 .

Contributors All authors developed this jointly.

Funding The authors have not declared a specific grant for this research from any funding agency in the public, commercial or not-for-profit sectors.

Competing interests None declared.

Patient consent for publication Not required.

Provenance and peer review Not commissioned; internally peer reviewed.

Data availability statement There are no data in this work.

Open access This is an open access article distributed in accordance with the Creative Commons Attribution Non Commercial (CC BY-NC 4.0) license, which permits others to distribute, remix, adapt, build upon this work non-commercially, and license their derivative works on different terms, provided the original work is properly cited, appropriate credit is given, any changes made indicated, and the use is non-commercial. See: http://creativecommons.org/licenses/by-nc/4.0/.

ORCID iD

Abdul Ghaffar http://orcid.org/0000-0002-8629-4526

\section{REFERENCES}

1 World Health Organization. What is health as a bridge for peace. Available: https://www.who.int/hac/techguidance/hbp/about/en/
2 Ottawa Charter for Health Promotion. World Health organization regional office for Europe, 1986. Available: https://www.euro.who. int/en/publications/policy-documents/ottawa-charter-for-healthpromotion,-1986 [Accessed May 7 2021].

3 United Nations. Who thematic paper on health and peace, 2020. Available: https://www.un.org/peacebuilding/sites/www.un.org. peacebuilding/files/un_pb_review__who_health_peace_thematic_ paper_final_0.pdf [Accessed May 7 2021].

4 Sight. COVID-19: an opportunity and a barrier to health as a bridge for peace in fragile and conflict-affected countries, 2020. Available: https://sight.nu/wp-content/uploads/2020/08/Policy-BriefCOVID19-pandemic-an-opportunity-and-barrier-to-HBP-140820.pdf [Accessed May 7 2021].

5 McMaster University. About peace through health, 2008. Available: https://www.humanities.mcmaster.ca/ peace_health/about.html [Accessed May 7 2021].

6 World Health Organization. Health as a bridge for peace. Available: https://www.who.int/hac/techguidance/hbp/en/ [Accessed May 7 2021].

7 United Nations. Security Council resolution 2282 on review of United nations Peacebuilding architecture, 2016. Available: https://www.un. org/press/en/2016/sc12340.doc.htm [Accessed May 7 2021].

8 World Health Organization. Thirteenth General programme of work 2019-2023, 2019. Available: https://www.who.int/about/what-we-do/ thirteenth-general-programme-of-work-2019-2023 [Accessed May 7 2021].

9 World Health Organization Regional Office for Europe. Who DirectorGeneral calls for health to be used as a bridge for peace between Israel and Palestine, 2018. Available: https://www.euro.who.int/ en/countries/israel/news/news/2018/3/who-director-general-callsfor-health-to-be-used-as-a-bridge-for-peace-between-israel-andpalestine [Accessed May 7 2021].

10 Commission on Social Determinants of Health in the Eastern Mediterranean Region. Build back fairer: achieving health equity in the eastern Mediterranean region: report of the Commission on social determinants of health in the eastern Mediterranean region - executive summary. Cairo: who regional office for the eastern Mediterranean, 2021. Available: http://www.emro.who.int/ media/news/report-of-the-commission-on-social-determinants-ofhealth-in-the-eastern-mediterranean-region.html [Accessed 12th May2021].

11 World Health Organization. Who health and peace initiative, 2020. Available: https://www.who.int/initiatives/who-health-and-peaceinitiative [Accessed 7 May 2021].

12 Abuelaish I, Goodstadt MS, Mouhaffel R. Interdependence between health and peace: a call for a new paradigm. Health Promot Int 2020;35:1590-600.

13 Worldbank. Fragility, Conflict \& Violence, 2021. Available: https:// www.worldbank.org/en/topic/fragilityconflictviolence/overview\% 231\&ie=UTF-8\&oe=UTF-8 [Accessed 7 May 2021].

14 MacQueen G, Santa-Barbara J, Neufeld V, et al. Health and peace: time for a new discipline. Lancet 2001;357:1460-1. 